\title{
Coffee crop science metric: A review
}

\author{
Carlos David Rodriguez Pabon' ${ }^{(\mathbb{D})}$, Juliana Sánchez-Benitez $z^{2}$ (D) Juan Ruiz-Rosero ${ }^{3}$ (D) Gustavo Ramirez-Gonzalez ${ }^{3}$ (D)
}

${ }^{1}$ University of Cauca, Telematic Engineering research Grou/GIT, Colombia

${ }^{2}$ Universidade Federal do Recôncavo da Bahia/UFRB, Cruz das Almas, BA, Brasil

${ }^{3}$ Telematic Engineering research Group/GIT, Colombia

Contact authors: davidrodriguez298@gmail.com, julianasanchezbenitez1@gmail.com,jpabloruiz@unicauca.edu.co, gramirez@unicauca.edu.co

Received in January 16, 2020 and approved in May 6, 2020

\begin{abstract}
Coffee is one of the leading worldwide drinks; therefore, it represents highly valued trade. However, coffee is a complex food from sowing to harvesting, processing, packaging, selling and consuming, although coffee is important in most of its stages, no studies have analyzed the dynamics of global coffee research. This paper presents an analysis of the evolution of Coffee related international research. It is based on the renowned literature databases published by Scopus and Web of Science. The parameters studied included growth of publications, the main journals, countries, institutions, and an author keywords analysis according to their relationship with topics such as agronomy, health, economy, chemistry or biological compound, product and unclassified words. Interest in harvesting techniques and coffee side factors have been increasing through last years in an exponential trend. Producer and consumer countries have composed a synergy with their research interest, that allows stating an upcoming growing in techniques headed to the quality beverage. The contribution is to visualize state of the art in the area of coffee knowledge to generate trends for future research.
\end{abstract}

Key words: Agronomy; scientopy; countries.

\section{INTRODUCTION}

Coffee is one of the oldest beverages. Which has apocryphal stories about its findings. It is originated in tropical Africa. Specifically, in Ethiopian highlands in about AD 850, from whence it was taken home by pilgrims to other parts of the Islamic world (Smith, 1985). Despite the first regulations by Arabs to control this product, other communities such as Dutch and French were able to cultivate it. Consequently, it has evolved through the years and regions where the coffee is produced and traded (Vieira, 2008).

Nowadays, coffee makes part of the lifestyle of people worldwide. As a beverage has its highest consumption rates in Europe and the United States (Samoggia; Riedel, 2018). As a crop, coffee is the most extensive agricultural trade (Murthy; Naidu, 2012a). It is cultivated in over 80 countries, where it represents a significant source of income for family farming (Damatta, 2004).

Due to the global importance of coffee, research has scaled most of the topics related to harvesting stages, sowing (Siles; Harmand; Vaast, 2010), maturing (Damatta; Ramalho, 2006; Damatta et al., 2007; Damatta, 2004; Moguel; Toledo, 1999), analyses on chemical composition (Rendón; Salva; Bragagnolo, 2014; Romano et al., 2014; Milenkovic et al., 2012; Cárdenas; Quesada; Medina, 2011), manufacturing process and trade (Taylor, 2005; States, 2017; Valkila; Haaparanta; Niemi, 2010; Utting, 2009). Side factors as pests and diseases (Waller, 1985; Kellermann et al., 2008; Posada et al., 2007; Avelino et al., 2015; Avelino et al., 2006; Silva et al., 2002; Schroth et al., 2000; Jaramillo et al., 2011; Jaramillo et al., 2009), ecosystem (Durán et al., 2005; Hoyos; Comerford, 2005; Muriel; Kattan, 2009; Alexander et al., 1998; Lautenbach et al., 2012; Perfecto et al., 2003; Méndez; Somarriba, 2001) and human health impacts (Higdon; Frei, 2006b; Poole et al., 2017; Rhee et al., 2016; Cenoz, 2013; Li et al., 2013; Ong; Hsu; Tan, 2012) associated to coffee crop have been also highlighted coffee as an interdisciplinary topic of research. Region, countries, and institutions have been focused on different aspects depending on their consumerproducer relationship, making coffee a topic that requires cooperation between parties.

Although coffee is important in most of its stages, no studies have analyzed the dynamics of global coffee research. Therefore, for this study, the research question considered was:

What are the main journals, countries, and author keywords on coffee in research articles published during 19902017 ?

We consider that this article contributes to enlarge knowledge about latest trends in coffee research, which can be used by policymakers in producer countries to allow improvements in bean quality. For consumer countries, this document gives a glance about research done related to impacts of this common beverage.

This study includes the following: (1) to identify the popular journals, representative countries, and primary institutions in the coffee research field; (2) to analyze the author keywords base and influential topics related to coffee; and (3) to uncover how the main author keywords have evolved over the last decades in different fields. 


\section{MATERIAL AND METHODS}

The bibliometric analysis consists of a statistical method used to measure research quality impact through the process of identifying, organizing, and analyzing the main components within a particular research field (Ruiz-Rosero; Ramirez-Gonzalez, 2018). The bibliometric method allows evaluating the contributions achieved by agents such as countries, institutions, and authors.

The tool used to analyze document bibliographies was a different literature review script called ScientoPy. It is a Python script that automatically reports the top topics (based on author keywords), authors, and countries, along with related documents. This automatic data synthesis avoids potential bias as in individual studies (Ruiz-Rosero et al., 2017; RuizRosero; Ramirez-Gonzalez, 2018).

\subsection{Dataset}

For bibliometric analysis, two databases were used: Clarivate Web of Science (WoS), and Scopus, which are considered as the world's largest abstract database and citation databases of peer-reviewed research literature. The span selected was 1 January 1990 to 31 December 2017. The following document types were studied: conference paper, article, review, proceedings paper, article in press.

The search was carried out with the string: "coffee". This string was applied to the topic search in WoS and Scopus, which include title, abstract, author keywords, and keywords plus R (for WoS). With this search criteria, the data set was extracted within a day on 6 September 2018. The documents found in the two databases totaled 60576 documents.

\subsection{Pre-Processing}

In order to improve the reliability and precision, ScientoPy applied the following criteria:

- For Scopus fields, replace the comma with a semicolon in author's name

- Remove dots, coma and special accents from author's name

- $\quad$ Remove duplicated samples were identified by identical title and authors

After the dataset samples were preprocessed, the information was consolidated and merged from both databases. Table 1 describes the final sample analyzed in this work included 44654 documents.

By undertaking the current study, we only showed a top ten selected topics, for the study about the evolution of scientific production and the first 400 words for the author keywords analysis based on highest h-index, classified by six categories: agronomy, health, economy, chemistry or biological compound, product, and generic unclassified words. However, the data set could undertake an in-depth analysis evolution of the research works on Coffee published.

Table 1. presents total loaded papers, omitted papers by document type, percentage relative to total loaded papers, papers from WoS, papers from Scopus, total duplicated papers found percentages relative to total loaded papers, removed duplicated papers from WoS percentage relative to papers from WoS, removed duplicated papers from Scopus percentage relative to papers from Scopus, duplicated documents with different cited by percentage relative to total duplicated papers found, output papers in range 1990 - 2017, and percentage relative to output papers (after duplication removal filter).

Table 1: Type of documents found with the search string "Coffee" loaded papers.

\begin{tabular}{ccc}
\hline Information & Number & Percentage \\
\hline Loaded paper result: & & \\
\hline Total papers & 60576 & \\
\hline Omitted papers by document type & 7162 & $11.8 \%$ \\
Total papers after omitted papers removed & 53411 & \\
Papers from WoS & 5191 & $7.2 \%$ \\
Papers from Scopus & 8222 & $2.8 \%$ \\
Duplicated removal results: & & \\
Total duplicated papers found & 757 & $6.4 \%$ \\
Removed duplicated papers from WoS & 6 & $0.3 \%$ \\
Removed duplicated papers from Scopus & 691 & $0.8 \%$ \\
Duplicated document with different cited by & 246 & $1.3 \%$ \\
Output papers (after duplication removal filter) & 44654 & \\
Output papers in range 1990-2017 & 37013 & $82.9 \%$ \\
\hline
\end{tabular}

\section{RESULTS AND DISCUSSION}

The first category analyzed was journals. In this classification, 70 journals published more than fifty articles related to coffee. Table 2 shows the top 10 journals with the highest number of articles published during the period 1990 to 2017. The journal with the highest number of articles published was Journal of Agricultural and Food Chemistry, with a total of 606 documents that represent $1.36 \%$ of the total published documents. The next journal was Food Chemistry with a total of 447 , and the third was Coffee Science with 390. Furthermore, table 2 also shows, the journal appears in the first place, its average growth rate (AGR) during the period: 2016 - 2017 was negative. So, it had a decrease in the produced articles. Instead, the second journal had an AGR positive in the same period. Coffee science has been publishing a constant number of articles, leading it to occupy the third position, its Hirsch index (h-index) is still small with only 11 . 
Table 2: Coffee topic highest number articles top 10 journals.

\begin{tabular}{ccccc}
$\mathrm{N}$ & Journal & Total & \multicolumn{2}{c}{ AGR } \\
h-ind \\
\hline 1 & Journal of Agricultural and Food Chemistry & 606 & -13.0 & 81 \\
2 & Food Chemistry & 447 & 10.5 & 59 \\
3 & Coffee Science & 390 & -0.5 & 11 \\
4 & Plos One & 322 & -10.5 & 34 \\
5 & Food Research International & 246 & 1.5 & 33 \\
6 & Ciencia e Agrotecnologia & 232 & -3.0 & 16 \\
7 & Pesquisa Agropecuária Brasileira & 188 & -4.5 & 23 \\
8 & American Journal of Clinical Nutrition & 169 & -4.5 & 62 \\
9 & Agroforestry Systems & 154 & 2.0 & 31 \\
10 & American Journal of Epidemiology & 142 & -3.0 & 66 \\
\hline
\end{tabular}

Journal number position $(\mathrm{N})$, total number of publications (Total), average growth rate from the last period studied (2016 - 2017), and $h$-index (h-ind).

Countries with the highest number of articles are shown in Figure 1. The United States (USA) with 5440 and Brazil with 3628 , accounts for $20.3 \%$ of the total number of articles published due to research on business value, improving and expanding the coffee production, compounds, composition, and impacts on human health. These countries formed the core of scientific production in this field and they present a rising curve in the quantity of document since 2004.

Moreover, the USA was the country with the highest h-index with 180, followed by the United Kingdom with 111, Germany with 93, Italy with 91 and France with 89. Despite Brazil holding the second in the articles published ranking, its AGR is only 78 .
Meanwhile, 53 institutions have published more than fifty articles. Figure 2 shows the ten institutions with the highest number of articles published. The institution with the highest number of articles published on this research field was Universidade Federal de Lavras, with a total of 418 articles. Also, the average growth rate (AGR) during the period 2016 - 2017 was positive for the first and third institution with 5.5 and 4.5 respectively. The Univ Fed Viscosa, Brazil with a total of 339 articles had a decrease of -7 in the number of articles published. The CIRAD institution from France with 135 articles is the highest AGR with 7.0 during this period. The institution's country was extracted from authors affiliations. According to the institutions rank, Brazil is the country with the highest total number of articles published, where, five from the first ten institutions belong to this country, followed by the United States and France.

\subsection{Author Keywords Analysis}

The author keywords in research articles define the field, subfield, topic, research issue, etc. that are covered by the article. Besides, other researchers can find papers when they are searching for the topic. The most electronic search engines, databases, or journal websites use author keywords to identify relevant papers and to show the papers to interested readers. Here, we analyzed the first 400 author keywords according to the best h-index for different research categories related to coffee. The author's keywords were classified by type, according to their relationship with the following macro topics, compounds, agronomy, product, economy, health, and generic words.
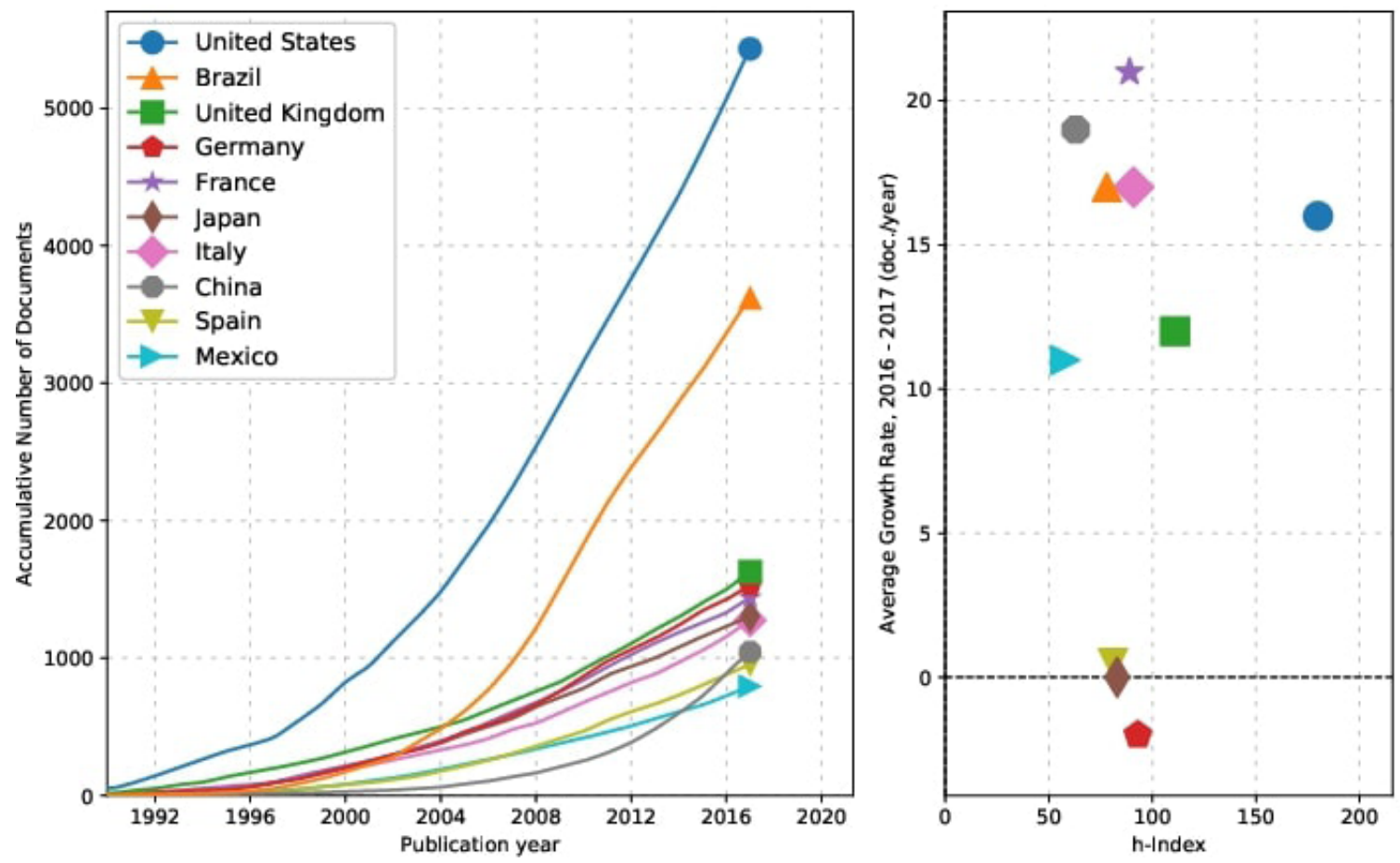

Figure 1: Ranking the most productive countries on Coffee. 

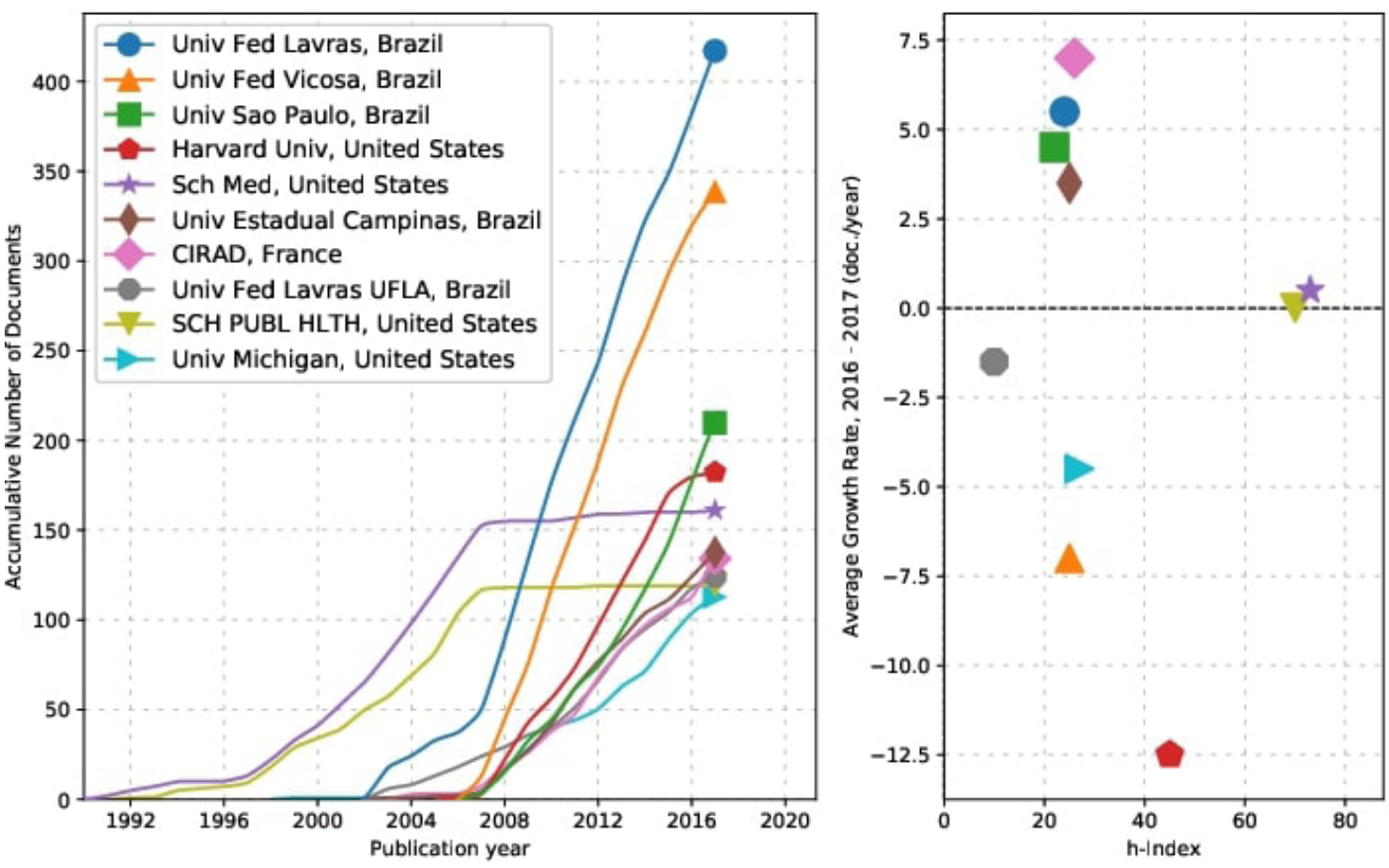

Figure 2: Ranking the most productive institutions in the country on coffee research.

Figure 3 shows the percentage of participation of each of these subgroups in the sample. Agronomy, health, and product stand out with the greatest participation, according to this they were analyzed separately. In addition, the importance of these subgroups lies in the incremental trend of the scientific production of coffee growing in these fields.

The words with semantic relationship "agronomy" were divided into four categories: plant health, coffee production system, coffee varieties, and other terms. Thus, a constant growth can be observed in relation to the publications that contain among its keywords, at least one word related to "agronomy". Figure 4 highlights the constant grown of publications related to production systems and coffee varieties.

In production system category, it is worth highlighting the most cited article, 366 times, this discusses the variety Coffea arabica and the pollination with bees for production (Klein; Steffan-Dewenter; Tscharntke, 2003), in addition, other topics related to this word are genetic diversity (Anthony et al. 2002; Anthony et al., 2001; Hecimovic et al., 2011), characteristics of the cultivar (Anthony et al., 2002; Noir et al., 2001; Quiroz-Figueroa et al., 2002) and coffee bean (Knopp; Bytof; Selmar, 2006; Bagdonaite; Derler; Murkovic, 2008; Bytof et al., 2005). As well as, one of the most cited words is agroforestry relating to biodiversity and environmental management with coffee production (Perfecto; Vandermeer, 2008; Tscharntke et al., 2008; Perfecto et al., 2005).

Health category has a similar proportion of publications related to the harmful effects of coffee and its derivatives, in addition to its beneficial effects. From the list of words, the most used by the authors during the period analyzed was diet (Johnston; Clifford; Morgan, 2003; Lutsey; Steffen; Stevens, 2008; Hanhineva et al., 2010; Calder et al., 2011; Peters et al., 1992), with an average number of 18 documents per year, nutrition (Hulshof et al., 2003; Graham et al., 1991; Zeegers et al., 2004; Graham et al., 1992; Baghurst et al., 1991), lifestyles (Nygard et al., 1998; Hassan; Killick, 2004; Matsumoto et al., 2003; El-Khairy et al., 1999), risk factors (Lindsay et al., 2002; Chang et al., 1997; Gomaa et al., 2008; Rasmussen, 1993; Refsum et al., 2006; Schulze et al., 2005) and mainly diseases such as Parkinson (Higdon; Frei, 2006a; Chen et al., 2001; Hu et al., 2007; Morano et al., 1994; Tan et al., 2003), obesity (Calder et al., 2011; Murase et al., 2011; Kamycheva; Joakimsen; Jorde, 2003; Dennis; Flack; Davy, 2009), diabetes (Scalbert et al., 2005; Fraser, 1999; Greenberg; Boozer; Geliebter, 2006; Mcglynn; Petrick; London, 2015; Montonen et al., 2005; Rosengren et al., 2004), hypertension (Suzuki et al., 2006; Jee et al., 1999; Hodgson et al., 1999; Watanabe et al., 2006; Habauzit; Morand, 2012), cancer (Somoza, 2005; Langner; Rzeski, 2014; Langner et al., 2013; Gasscht; Dicato; Diederich, 2015; Fraser, 1999; Weisburger; Chung, 2002; Ghadirian; Lynch; Krewski, 2003) and cardiovascular diseases (Dam, 2008; Heidemann et al., 2009; Grosso et al., 2017; Grosso et al., 2016; Ferrari et al., 2016).

The words with semantic relationship "product" correspond to the set of words related to post-harvest coffee processing, which were divided into four categories: Coffee characteristics, product presentation, comparison between similar drinks and manufacturing processes. The features 
category has had great growth in publications in recent years, reaching more than 100 publications in $2017,43 \%$ of the subsamples analyzed. It emphasizes words such as food (Nicoli et al., 1997; Svensson et al., 2003; Jorgensen, 1998), Beverages (Pellegrini et al., 2003; Mattila; Hellstrom; Torronen, 2006; Richelle; Tavazzi; Offord, 2001) and Aroma (Yeretzian et al., 2002; Sunarharum; Williams; Smyth, 2014). In the presentation the most highlights words are espresso coffee (Mussatto et al., 2011; Corti et al., 2002; Parras et al., 2007), instant coffee (Kilmartin; Hsu, 2003; Charlton; Farrington; Brereton, 2002; Briandet; Kemsley; Wilson, 1996), and coffee pulp (Prata; Oliveira, 2007; Avallone et al., 2000). Next, coffee is mainly compared to products such as tea (Nawrot et al., 2003; Popkin et al., 2006; Hurrell; Reddy; Cook, 1999; Natella et al., 2002), wine (Svilaas et al., 2004;
Valls-Pedret et al., 2012; Ferrari; Torres, 2003) and cocoa (Ferrari; Torres, 2003; Morales; Somoza; Fogliano, 2012; Moco et al., 2012).

Finally, The main manufacturing processes are roasting (Castillo; Ames; Gordon, 2002; Nunes; Coimbra, 2001; Nunes; Coimbra, 2007; Yeretzian et al., 2002), drying (Andriot; Quere; Guichard, 2004; Fadai et al., 2017; Marques et al., 2008) and fermentation (Lima; Vieira; Martins, 2008; Murthy; Naidu, 2012b; Silva et al., 2000).

In the generic category, there are words that cannot be classified in the categories defined by this study because they can belong to all categories or none of them, some of the words found in this category are analysis, quality metaanalysis, review, case-control study, systematic review, validation among other.

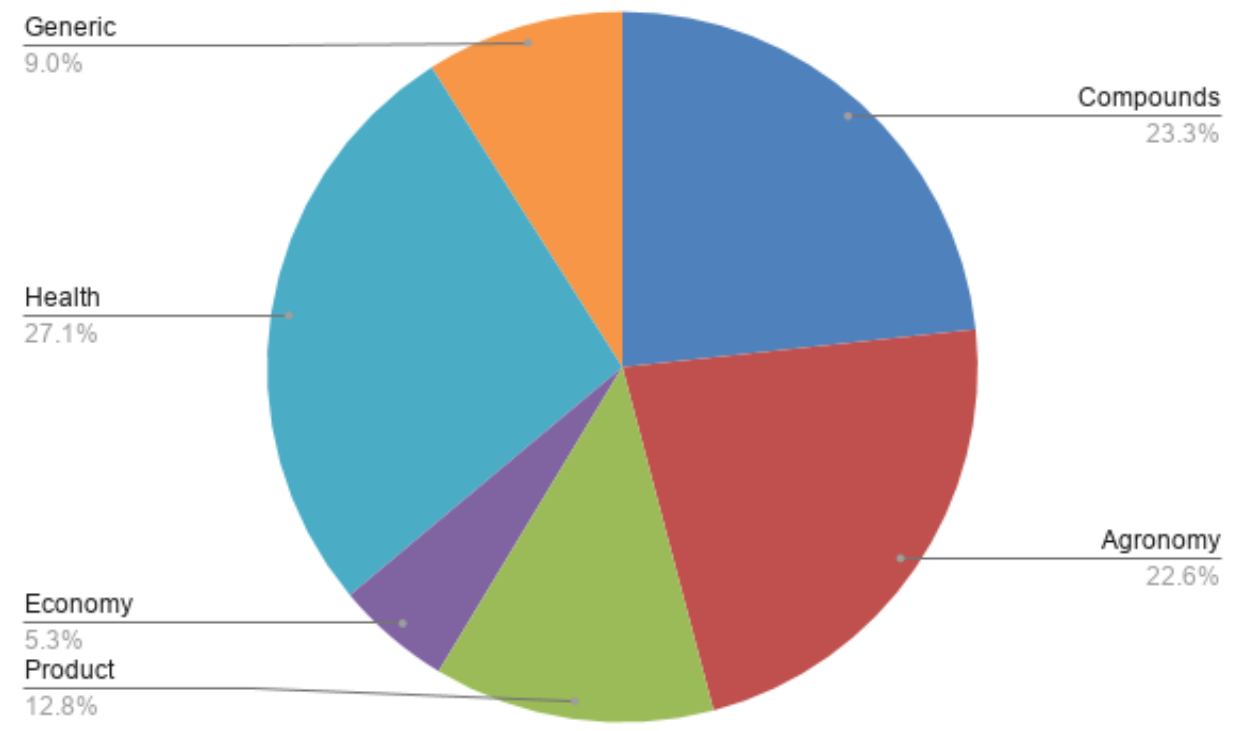

Figure 3: Author keywords classification.

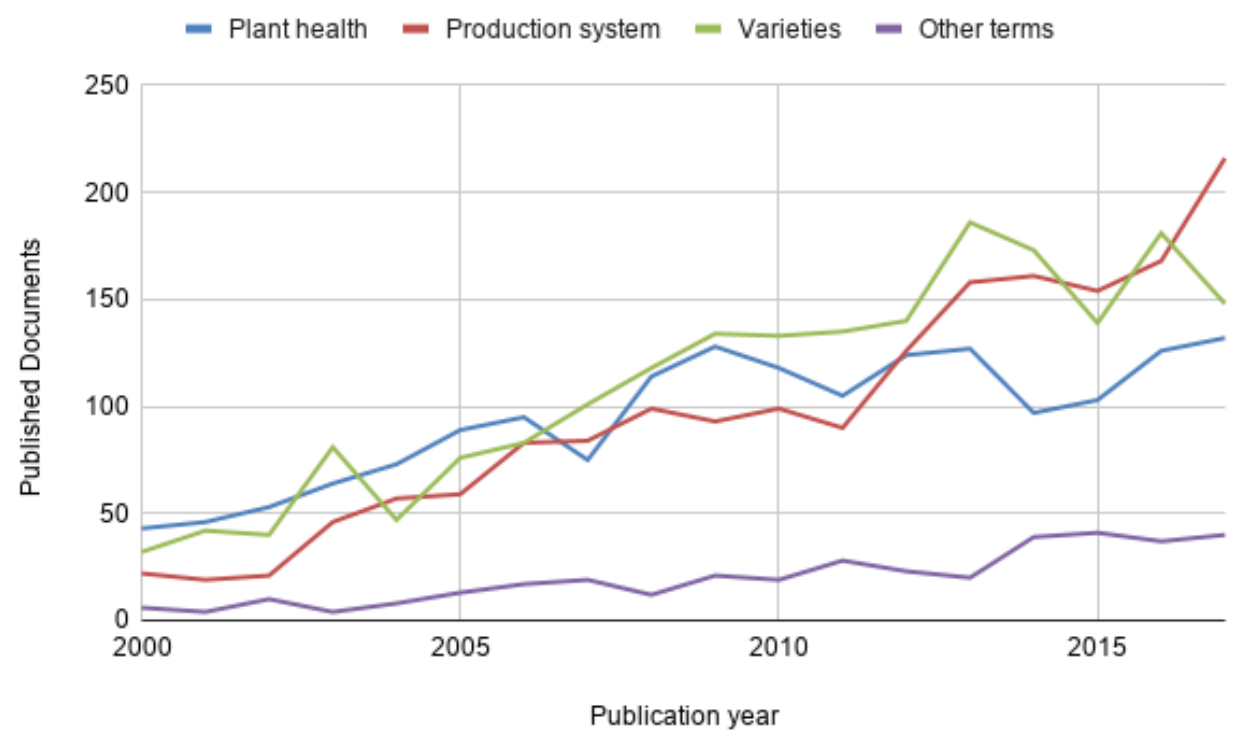

Figure 4: Agronomy classification. 


\section{CONCLUSIONS}

This paper presents a bibliometric analysis of coffee research. The main goal of this study is to identify and classify the systematically the scholarly articles from 1990 to 2017 , integrating subject categories of journals, countries, and author keywords. The results show a remarkable grown in articles per year, from 184 and 118 articles published from 1990 to 2068 and 2046 in 2017 for Scopus and WoS respectively.

Coffee research has been a challenge for both consumers and producers' countries. The United States and Brazil are the principal participants in this research field, this due to business value, the need for improving and expanding the coffee production, to know the compounds, composition, and impacts on human health

In the analysis of the author's keywords, Caffeine is the component with the most articles published in the period studied, they focus on the relationship with different diseases, as well as the chemical composition. In the agronomy category, the problems related to the production system and coffee varieties are the fastest growing in recent years.

However, this analysis is only an approach that might be complemented by a more in-depth analysis. The results obtained to give a theoretical point of view, state of the art on the subject could be mapped, and gaps in the scientific research could be easily identified. This analysis bibliometric intends to be a reference for future works in the development of coffee analysis on topics such as the risks for human health, some kinds of cancer or even study depth specific topics that we have presented.

\section{ACKNOWLEDGMENTS}

The authors wish to thank the University of Cauca, the Telematic Engineering research Group (GIT), the project called "Innovative Alternatives of Smart Agriculture for agricultural production systems of the department of Cauca supported in IoT environments" InnovAccion-Cauca, from the General Royalties System, and the Government of Cauca (Colombia). The author 2 thanks the Federal University of Recôncavo da Bahia, Brazil, especially the postgraduate program in Agricultural Engineering for training and Capes for scholarship.

Dataset. The dataset is available on: https://drive. google.com/drive/folders/1Ib_8oifc46jvA9Qe8_lwcmM9qeg142f?usp=sharing.

ScientoPy. ScientoPy is available on: https://github. com/jpruiz84/ScientoPy.

\section{REFERENCES}

ALEXANDER, B. et al. Detection of Leishmania (Viannia) braziliensis complex in wild mammals from Colombian coffee plantations by PCR and DNA hybridization. Acta tropica, 69(1):41-50, 1998.

ANDRIOT, I.; QUERE, J. L.; GUICHARD, E. Interactions between coffee melanoidins and flavour compounds: Impact of freeze-drying (method and time) and roasting degree of coffee on melanoidins retention capacity. Food Chemistry, 85(3):289-294, 2004.

ANTHONY, F. et al. Genetic diversity of wild coffee (coffea arabica 1.) using molecular markers. Euphytica, 118:5365,2001

ANTHONY, F. et al. The origin of cultivated coffea arabica 1. varieties revealed by aflp and ssr markers. Theoretical and Applied Genetics, 104(5):894-900, 2002.

AVALLONE, S. et al. Polysaccharide constituents of coffeebean mucilage. Journal of Food Science, 65(8):13081311, 2000.

AVELINO, J. et al. The coffee rust crises in Colombia and Central America (2008-2013): Impacts, plausible causes and proposed solutions. Food Security, 7(2):303-321, 2015.

AVELINO, J. et al. The intensity of a coffee rust epidemic is dependent on production situations. Ecological Modelling, 197(3-4):431-447, 2006.

BAGDONAITE, K.; DERLER, K.; MURKOVIC, M. Determination of acrylamide during roasting of coffee. Journal of Agricultural and Food Chemistry, 56(15):6081-6086, 2008.

BAGHURST, P. et al. A case-control study of diet and cancer of the pancreas. American Journal of Epidemiology, 134(2):167-179, 1991.

BRIANDET, R.; KEMSLEY, E.; WILSON, R. Discrimination of arabica and robusta in instant coffee by fourier transform infrared spectroscopy and chemometrics. Journal of Agricultural and Food Chemistry, 44(1):170-174, 1996.

BYTOF, G. et al. Influence of processing on the generation of g-aminobutyric acid in green coffee beans. European Food Research and Technology, 220:245-250, 2005.

CALDER, P. et al. Dietary factors and low-grade inflammation in relation to overweight and obesity. British Journal of Nutrition, 106(S3):S5-S78, 2011.

CÁRDENAS, C.; QUESADA, A. R.; MEDINA, M. A. Antiangiogenic and anti-inflammatory properties of kahweol, a coffee diterpene. PLoS ONE, 6(8):e23407, 2011. 
CASTILlO, M. del; AMES, J.; GORDON, M. Effect of roasting on the antioxidant activity of coffee brews. Journal of Agricultural and Food Chemistry, 50(13):3698-3703, 2002.

CENOZ, J. Studies in second language acquisition Cambridge. University Press, 35(4):757-761, 2013.

CHANG, P. et al. Insomnia in young men and subsequent depression - The johns hopkins precursors study. American Journal of Epidemiology, 146(2):105-114, 1997.

CHARLTON, A.; FARRINGTON, W.; BRERETON, P. Application of h-1 nmr and multivariate statistics for screening complex mixtures: Quality control and authenticity of instant coffee. Journal of Agricultural and Food Chemistry, 50(11):3098-3103, 2002.

CHEN, J. et al. Neuroprotection by caffeine and a (2a) adenosine receptor inactivation in a model of parkinson's disease. Journal of Neuroscience, 21(10):RC143, 2001.

CORTI, R. et al. Coffee acutely increases sympathetic nerve activity and blood pressure independently of caffeine content - Role of habitual versus non habitual drinking. Circulation, 106:2935-2940, 2002.

DAM, R. M. van. Coffee consumption and risk of type 2 diabetes, cardiovascular diseases, and cancer. Applied Physiology Nutrition and Metabolism- Physiologie Appliquee Nutrition et Metabolisme, 33(6):1269-1283, 2008.

DAMATTA, F. M. Ecophysiological constraints on the production of shaded and unshaded coffee: A review. Field Crops Research, 86(2-3):99-114, 2004.

DAMATTA, F. M.; RAMALHO, J. D. C. Impacts of drought and temperature stress on coffee physiology and production: A review. Brazilian Journal of Plant Physiology, 18(1):55-81, 2006.

DAMATTA, F. M. et al. Ecophysiology of coffee growth and production. Brazilian Journal of Plant Physiology, 19(4):485-510, 2007.

DENNIS, E. A.; FLACK, K. D.; DAVY, B. M. Beverage consumption and adult weight management: A review. Eating Behaviors, 10(4):237-246, 2009.

DURÁN, S. M. et al. A test of the utility of exotic tree plantations for understory birds and food resources in the Colombian andes. Biotropica, 37(1):129-135, 2005.

EL-KHAIRY, L. et al. Lifestyle and cardiovascular disease risk factors as determinants of total cysteine in plasma:
The hordaland homocysteine study. American Journal of Clinical Nutrition, 70(6):1016-1024, 1999.

FADAI, N. T. et al. A heat and mass transfer study of coffee bean roasting. International Journal of Heat and Mass Transfer, 104:787-799, 2017.

FERRARI, C.; TORRES, E. Biochemical pharmacology of functional foods and prevention of chronic diseases of aging. Biomedicine \& Pharmacotherapy, 57(5-6):251260, 2003.

FERRARI, C. K. B. et al. An apple plus a brazil nut a day keeps the doctors away: Antioxidant capacity of foods and their health benefits. Current Pharmaceutical Design, 229(2):189-195, 2016

FRASER, G. Associations between diet and cancer, ischemic heart disease, and all-cause mortality in non-hispanic white california seventh-day adventists. American Journal of Clinical Nutrition, 70(3):532S-538S, 1999.

GASSCHT, F.; DICATO, M.; DIEDERICH, M. Coffee provides a natural multitarget pharmacopeia against the hallmarks of cancer. Genes and Nutrition, 10(6):51, 2015 .

GHADIRIAN, P.; LYNCH, H.; KREWSKI, D. Epidemiology of pancreatic cancer: An overview. Cancer Detection and Prevention, 27(1):87-93, 2003.

GOMAA, A. I. et al. Hepatocellular carcinoma: Epidemiology, risk factors and pathogenesis. World Journal of Gastroenterology, 14(27):4300-4308, 2008.

GRAHAM, S. et al. Nutritional epidemiology of postmenopausal breast-cancer in western new-york. American Journal of Epidemiology, 134(6):552-552, 1991.

GRAHAM, S. et al. Diet in the epidemiology of postmenopausal breast-cancer in the new-yorkstate cohort. American Journal of Epidemiology, 136(11):1327-1337, 1992.

GREENBERG, J. A.; BOOZER, C. N.; GELIEBTER, A. Coffee, diabetes, and weight control. American Journal of Clinical Nutrition, 84(4):682-693, 2006.

GROSSO, G. et al. Coffee, caffeine, and health outcomes: An umbrella review. Annual Review of Nutrition, 37:131$156,2017$.

GROSSO, G. et al. Coffee consumption and risk of all-cause, cardiovascular, and cancer mortality in smokers and non-smokers: A dose-response meta-analysis. European Journal of Epidemiology, 31:1191-1205, 2016. 
HABAUZIT, V.; MORAND, C. Evidence for a protective effect of polyphenols-containing foods on cardiovascular health: An update for clinicians. Therapeutic Advances in Chronic Disease, 3(2):87-106, 2012.

HANHINEVA, K. et al. Impact of dietary polyphenols on carbohydrate metabolism. International Journal of Molecular Sciences, 11(4):1365-1402, 2010.

HASSAN, M.; KILLICK, S. Negative lifestyle is associated with a significant reduction in fecundity. Fertility and Sterility, 81(2):384-392, 2004.

HECIMOVIC, I. et al. Comparative study of polyphenols and caffeine in different coffee varieties affected by the degree of roasting. Food Chemistry, 129(3):991-1000, 2011.

HEIDEMANN, C. et al. Association of a diabetes risk score with risk of myocardial infarction, stroke, specific types of cancer, and mortality: A prospective study in the european prospective investigation into cancer and nutrition (epic)-potsdam cohort. European Journal of Epidemiology, 24(6):281-288, 2009.

HIGDON, J.; FREI, B. Coffee and health: A review of recent human research. Critical Reviews in Food Science and Nutrition, 46(2):101-123, 2006a.

HIGDON, J. V.; FREI, B. Coffee and health: A review of recent human research. Critical Reviews in Food Science and Nutrition, 46(2):101-123, $2006 \mathrm{~b}$.

HODGSON, J. et al. Effects on blood pressure of drinking green and black tea. Journal of Hypertension, 17(4):457-463, 1999.

HOYOS, N.; COMERFORD, N. B. Land use and landscape effects on aggregate stability and total carbon of Andisols from the Colombian Andes. Geoderma, 129(3-4):268$278,2005$.

HU, G. et al. Coffee and tea consumption and the risk of parkinson's disease. Movement Disorders, 22(15):22422248, 2007.

HULSHOF, K. et al. Socio-economic status, dietary intake and $10 \mathrm{y}$ trends: the dutch national food consumption survey. European Journal of Clinical Nutrition, 57(1):128-137, 2003.

HURRELL, R.; REDDY, M.; COOK, J. Inhibition of nonhaem iron absorption in man by polyphenolic-containing beverages. British Journal of Nutrition, 81(4):289-295, 1999.

JARAMILLO, J. et al. Thermal tolerance of the coffee berry borer Hypothenemus hampei: Predictions of climate change impact on a tropical insect pest. PLoS ONE, 4(8):1-11, 2009.

JARAMILLO, J. et al. Some like it hot: The influence and implications of climate change on coffee berry borer (Hypothenemus hampei) and coffee production in East Africa. PLoS ONE, 6(9):e24528, 2011.

JEE, S. et al. The effect of chronic coffee drinking on blood pressure - A meta-analysis of controlled clinical trials. Hypertension, 33(2):647-652, 1999.

JOHNSTON, K.; CLIFFORD, M.; MORGAN, L. Coffee acutely modifies gastrointestinal hormone secretion and glucose tolerance in humans: Glycemic effects of chlorogenic acid and caffeine. American Journal of Clinical Nutrition, 78(4):728-733, 2003.

JORGENSEN, K. Survey of pork, poultry, coffee, beer and pulses for ochratoxin a. Food Additives and Contaminants, 15(5):550-554, 1998.

KAMYCHEVA, E.; JOAKIMSEN, R.; JORDE, R. Intakes of calcium and vitamin d predict body mass index in the population of northern norway. Journal of Nutrition, 133(1):102-106, 2003

KELLERMANN, J. L. et al. Ecological and economic services provided by birds on Jamaican Blue Mountain coffee farms. Conservation Biology, 22(5):1177-1185, 2008.

KILMARTIN, P.; HSU, C. Characterisation of polyphenols in green, oolong, and black teas, and in coffee, using cyclic voltammetry. Food Chemistry, 82(4):501-512, 2003.

KLEIN, A.; STEFFAN-DEWENTER, I.; TSCHARNTKE, T. Fruit set of highland coffee increases with the diversity of pollinating bees. Proceedings of The Royal Society B-Biological Sciences, 270:955-961, 2003.

KNOPP, S.; BYTOF, G.; SELMAR, D. Influence of processing on the content of sugars in green arabica coffee beans. European Food Research and Technology, 223:195-201, 2006.

LANGNER, E. et al. Melanoidins isolated from heated potato fiber (potex) affect human colon cancer cells growth via modulation of cell cycle and proliferation regulatory proteins. Food and Chemical Toxicology, 57:246-255, 2013.

LANGNER, E.; RZESKI, W. Biological properties of melanoidins: A review. International Journal of Food Properties, 17(2):344-353, 2014. 
LAUTENBACH, S. et al. Spatial and temporal trends of global pollination benefit. PLoS ONE, 7(4):e35954, 2012.

LI, X. J. et al. Coffee Consumption and Risk of Breast Cancer: An Up-To-Date Meta-Analysis. PLoS ONE, 8(1):e52681, 2013.

LIMA, M. V.; VIEIRA, H. D.; MARTINS, M. L. L. Electric conductivity as indicator of coffee depulped during degumming. Ciência Rural, 38(6):1765-1768, 2008 .

LINDSAY, J. et al. Risk factors for alzheimer's disease: A prospective analysis from the canadian study of health and aging. American Journal of Epidemiology, 156(5):445-453, 2002.

LUTSEY, P. L.; STEFFEN, L. M.; STEVENS, J. Dietary intake and the development of the metabolic syndrome - The atherosclerosis risk in communities study. Circulation, 117(12):754-761, 2008.

MARQUES, E. R. et al. Efficiency of fatty acidity test on the evaluation of the quality of arabic coffee (c.a) submitted to different dry periods and temperatures. Ciência e Agrotecnologia, 32(5):1557-1562, 2008.

MATSUMOTO, A. et al. Bisphenol a levels in human urine. Environmental. Health Perspectives, 111(1):101-104, 2003.

MATTILA, P.; HELLSTROM, J.; TORRONEN, R. Phenolic acids in berries, fruits, and beverages. Journal of Agricultural and Food Chemistry, 54(19):7193-7199, 2006.

MCGLYNN, K. A.; PETRICK, J. L.; LONDON, W. T. Global epidemiology of hepatocellular carcinoma an emphasis on demographic and regional variability. Clinics in Liver Disease, 19(2):223-38, 2015.

MÉNDEZ, V. E.; SOMARRIBA, E. J. Interdisciplinary analysis of homegardens in Nicaragua: Micro-zonation, plant use and socioeconomic importance. Agroforestry Systems, 51(2):85-96, 2001.

MILENKOVIC, D. et al. Modulation of miRNA expression by dietary polyphenols in apoE deficient mice: A new mechanism of the action of polyphenols. PLoS ONE, 7(1):e29837, 2012.

MOCO, S.; MARTIN, F.-P. J.; REZZI, S. Metabolomics view on gut microbiome modulation by polyphenol-rich foods. Journal of Proteome Research, 11(10):4781-4790, 2012.
MOGUEL, P.; TOLEDO, V. M. Biodiversity conservation in tradicional Coffee systems of Mexico. Conservation Biology, 13(1):11-21, 1999

MONTONEN, J. et al. Food consumption and the incidence of type II diabetes mellitus. European Journal of Clinical Nutrition, 59(3): 441-448, 2005.

MORALES, F. J.; SOMOZA, V.; FOGLIANO, V. Physiological relevance of dietary melanoidins. Amino Acids, 42:1097-1109, 2012.

MORANO, A. et al. Risk-factors for parkinson's disease: Case-control study in the province of caceres, spain. Acta Neurologica Scandinavica, 89(3):164-170, 1994.

MURASE, T. et al. Coffee polyphenols suppress diet-induced body fat accumulation by downregulating srebp-1c and related molecules in c57bl/6j mice. American Journal of Physiology-Endocrinology and Metabolism, 300(1):E122-E133, 2011.

MURIEL, S. B.; KATTAN, G. H. Effects of patch size and type of coffee matrix on ithomiine butterfly diversity and dispersal in cloud-forest fragments. Conservation Biology, 23(4):948-956, 2009.

MURTHY, P. S.; NAIDU, M. M. Sustainable management of coffee industry by-products and value addition - A review. Resources, Conservation and Recycling, 66:45-58, 2012a.

MURTHY, P. S.; NAIDU, M. M. Sustainable management of coffee industry by-products and value addition - A review. Resources Conservation and Recycling, 66:45-58, 2012b.

MUSSATTO, S. I. et al. Production, composition, and application of coffee and its industrial residues. Food and Bioprocess Technology, 4:661-672, 2011.

NATELLA, F. et al. Coffee drinking influences plasma antioxidant capacity in humans. Journal of Agricultural and Food Chemistry, 50(21):6211-6216, 2002.

NAWROT, P. et al. Effects of caffeine on human health. Food Additives and Contaminants Part A-Chemistry Analysis Control Exposure \& Risk Assessment, 20(1):1-30, 2003.

NICOLI, M. et al. Loss and/or formation of antioxidants during food processing and storage. Cancer Letters, 114(1-2):71-74, 1997.

NOIR, S. et al. Origin, diversity and evolution of nbs-type disease-resistance gene homologues in coffee trees (coffea 1.). Molecular Genetics and Genomics, 265:654-662, 2001. 
NUNES, F.; COIMBRA, M. Chemical characterization of the high molecular weight material extracted with hot water from green and roasted arabica coffee. Journal of Agricultural and Food Chemistry, 49(4):1773-1782, 2001 .

NUNES, F. M.; COIMBRA, M. A. Melanoidins from coffee infusions. fractionation, chemical characterization, and effect of the degree of roast. Journal of Agricultural and Food Chemistry, 55(10):3967-3977, 2007.

NYGARD, O. et al. Major lifestyle determinants of plasma total homocysteine distribution: The hordaland homocysteine study. American Journal of Clinical Nutrition, 67(2):263-270, 1998.

ONG, K. W.; HSU, A.; TAN, B. K. H. Chlorogenic acid stimulates glucose transport in skeletal muscle via AMPK activation: A contributor to the beneficial effects of coffee on diabetes. PLoS ONE, 7(3):e32718, 2012.

PARRAS, P. et al. Antioxidant capacity of coffees of several origins brewed following three different procedures. Food Chemistry, 102(3):582-592, 2007.

PELLEGRINI, N. et al. Total antioxidant capacity of plant foods, beverages and oils consumed in Italy assessed by three different in vitro assays. Journal of Nutrition, 133(9):2812-2819, 2003.

PERFECTO, I. et al. Conservation of biodiversity in coffee agroecosystems: A tri-taxa comparison in southern Mexico. Biodiversity and Conservation, 12(6):1239-1252, 2003.

PERFECTO, I.; VANDERMEER, J. Biodiversity conservation in tropical agroecosystems - A new conservation paradigm. Year in Ecology and Conservation Biology, 1134:173-200, 2008.

PERFECTO, I. et al. Biodiversity, yield, and shade coffee certification. Ecological Economics, 54(4):435-446, 2005.

PETERS, R. et al. Diet and colon cancer in Los Angeles county, california. Cancer Causes \& Control, 3(5):457473, 1992.

POOLE, R. et al. Coffee consumption and health: Umbrella review of meta-analyses of multiple health outcomes. BMJ (Clinical research ed.), 359:j5024, 2017.

POPKIN, B. et al. A new proposed guidance system for beverage consumption in the United States. American Journal of Clinical Nutrition, 83(3):529-542, 2006.

POSADA, F. et al. Inoculation of coffee plants with the fungal entomopathogen Beauveria bassiana (Ascomycota: Hypocreales). Mycological Research, 111(6):748-757, 2007.
PRATA, E. R. B. A.; OLIVEIRA, L. S. Fresh coffee husks as potential sources of anthocyanins. Lwt-Food Science and Technology, 40:1555-1560, 2007.

QUIROZ-FIGUEROA, F. et al. Histological studies on the developmental stages and differentiation of two different somatic embryogenesis systems of coffea arabica. Plant Cell Reports, 20:1141-1149, 2002.

RASMUSSEN, B. Migraine and tension-type headache in a general-population - Precipitating factors, female hormones, sleep pattern and relation to life-style. Pain, 53(1):65-72, 1993.

REFSUM, H. et al. The hordaland homocysteine study: A community-based study of homocysteine, its determinants, and associations with disease. Journal of Nutrition, 136(6):1731S-1740S, 2006.

RENDÓN, M. Y.; SALVA, T. D. J. G.; BRAGAGNOLO, N. Impact of chemical changes on the sensory characteristics of coffee beans during storage. Food Chemistry, 147:279-286, 2014

RHEE, J. J. et al. Coffee and caffeine consumption and the risk of hypertension in postmenopausal women. American Journal of Clinical Nutrition, 103(1):210$217,2016$.

RICHELLE, M.; TAVAZZI, I.; OFFORD, E. Comparison of the antioxidant activity of commonly consumed polyphenolic beverages (coffee, cocoa, and tea) prepared per cup serving. Journal of Agricultural and Food Chemistry, 49(7):34383442, 2001.

ROMANO, R. et al. Identification markers based on fatty acid composition to differentiate between roasted Arabica and Canephora (Robusta) coffee varieties in mixtures. Journal of Food Composition and Analysis, 35(1):1-9, 2014.

ROSENGREN, A. et al. Coffee and incidence of diabetes in swedish women: a prospective 18-year follow-up study. Journal of Internal Medicine, 255(1):89-95, 2004.

RUIZ-ROSERO, J.; RAMIREZ-GONZALEZ, G. ScientoPy: a scientometric tool for topics trend analysis in scientific publications. (Paper Submitted to). Scientometrics, 121:1165-1188, 2018.

RUIZ-ROSERO, J. et al. Internet of things: A scientometric review. Symmetry, 9(12):301, 2017.

SAMOGGIA, A.; RIEDEL, B. Coffee consumption and purchasing behavior review: Insights for further research. Appetite, 129:70-81, 2018. 
SCALBERT, A. et al. Dietary polyphenols and the prevention of diseases. Critical Reviews in Food Science and Nutrition, 45(4):287-306, 2005.

SCHROTH, G. et al. Pests and diseases in agroforestry systems of the humid tropics.Agroforestry Systems, 50(3):199-241, 2000.

SCHULZE, M. et al. Dietary pattern, inflammation, and incidence of type 2 diabetes in women. American Journal of Clinical Nutrition, 82(3):675-684, 2005.

SILES, P.; HARMAND, J. M.; VAAST, P. Effects of Inga densiflora on the microclimate of coffee (Coffea arabica L.) and overall biomass under optimal growing conditions in Costa Rica. Agroforestry Systems, 78(3):269-286, 2010.

SILVA, C. et al. Microbial diversity during maturation and natural processing of coffee cherries of coffea arabica in Brazil. International Journal of Food Microbiology, 60(2-3)251-260, 2000.

SILVA, M. C. et al. Hypersensitive cell death and posthaustorial defence responses arrest the orange rust (Hemileia vastatrix) growth in resistant coffee leaves. Physiological and Molecular Plant Pathology, 60(4):169-183, 2002.

SMITH, R. F. A History of Coffee. In: CLIFFORD, M. N.; WILLSON, K. C. (Eds.). Coffee. Springer: Boston, MA. 1985. p.1-12.

SOMOZA, V. Five years of research on health risks and benefits of maillard reaction products: An update. Molecular Nutrition \& Food Research, 49(7):663-672, 2005.

STATES, U. coffee-world-markets-and-trade Approved by the World Agricultural Outlook Board/USDA. 2017. 8p. Available in: <https://apps.fas.usda.gov/psdonline/circulars/ coffee.pdf $>$. Access in: September, 18, 2018..

SUNARHARUM, W. B.; WILLIAMS, D. J.; SMYTH, H. E. Complexity of coffee flavor: A compositional and sensory perspective. Food Research International, 62:315-325, 2014.

SUZUKI, A. et al. Chlorogenic acid attenuates hypertension and improves endothelial function in spontaneously hypertensive rats. Journal of Hypertension, 24(6):10651073, 2006.

SVENSSON, K. et al. Dietary intake of acrylamide in sweden. Food and Chemical Toxicology, 41(11):1581$1586,2003$.

SVILAAS, A. et al. Intakes of antioxidants in coffee, wine, and vegetables are correlated with plasma carotenoids in humans. Journal of Nutrition, 134(3):562-567, 2004.
TAN, E. et al. Dose-dependent protective effect of coffee, tea, and smoking in parkinson's disease: A study in ethnic chinese. Journal of the Neurological Sciences, 216(1):163-167, 2003.

TAYLOR, P. L. In the market but not of it: Fair trade coffee and forest stewardship council certification as marketbased social change. World Development, 33(1):129$147,2005$.

TSCHARNTKE, T. et al. Landscape constraints on functional diversity of birds and insects in tropical agroecosystems. Ecology, 89(4):944-951, 2008.

UTTING, K. Assessing the impact of fair trade coffee: Towards an integrative framework. Journal of Business Ethics, 86(SUPPL. 1):127-149, 2009.

VALKILA, J.; HAAPARANTA, P.; NIEMI, N. Empowering Coffee Traders? The Coffee Value Chain from Nicaraguan Fair Trade Farmers to Finnish Consumers. Journal of Business Ethics, 97(2):257-270, 2010

VALLS-PEDRET, C. et al. Polyphenol-rich foods in the mediterranean diet are associated with better cognitive function in elderly subjects at high cardiovascular risk. Journal of Alzheimers Disease, 29(4):773-782, 2012.

VIEIRA, H. D. Coffee: The plant and its cultivation. PlantParasitic Nematodes of Coffee, p. 3-18, 2008.

WALLER, J. M. Control of Coffee Diseases. In: Coffee. Boston, MA: Springer US, 1985. p.219-229. Available in: $<$ http://link.springer.com/10.1007/978-1-4615-6657-1_9>. Access in: September, 25, 2018.

WATANABE, T. et al. The blood pressure-lowering effect and safety of chlorogenic acid from green coffee bean extract in essential hypertension.

Clinical and Experimental Hypertension, 28(5):439-449, 2006.

WEISBURGER, J.; CHUNG, F. Mechanisms of chronic disease causation by nutritional factors and tobacco products and their prevention by tea polyphenols. Food and Chemical Toxicology, 40(8):1145-1154, 2002 .

YERETZIAN, C. et al. From the green bean to the cup of coffee: investigating coffee roasting by on-line monitoring of volatiles. European Food Research and Technology, 214:92-104, 2002.

ZEEGERS, M. et al. The association between smoking, beverage consumption, diet and bladder cancer: A systematic literature review. World Journal of Urology, 21(6):392-401, 2004. 